\title{
Double anti-PL-7 and anti-MDA-5 positive Amyopathic Dermatomyositis with rapidly progressive interstitial lung disease in a Hispanic patient
}

\author{
Zi Ying $\mathrm{Li}^{1,2^{*}} \mathbb{D}$, Evanpaul Gill', Fan Mo ${ }^{1}$ and Candice Reyes ${ }^{3}$
}

\begin{abstract}
Background: Each myositis-specific autoantibody (MSA) tends to have a distinct clinical presentation. Coexistence of MSAs do not commonly occur. If they do, it is unknown if there is an overlap of clinical features or prognostic implications. There are a few reported cases of overlap between these antibodies, mostly reported in patients with Japanese descent. Our aim for this case report is to turn more attention and interest for future MSA profile studies in the Hispanic population, which may hopefully spur better therapies if we realize the prognostic implications of certain myositis subsets including double-positive autoantibody syndromes.
\end{abstract}

Case presentation: A 27-year-old Hispanic female was admitted to the medical intensive care unit due to acute hypoxemic respiratory failure secondary to acute respiratory distress syndrome (ARDS). She had failed conventional mechanical ventilation and was cannulated for venovenous extracorporeal membrane oxygenation (W-ECMO) to manage her respiratory failure. She had erythematous scaly plaques on bilateral 3rd metacarpophalangeal joints on examination. Her autoimmune workup revealed positivity for both anti-PL-7(threonyl) and anti-melanoma differentiation-associated gene 5 (MDA5) autoantibodies. After extensive evaluation, it was concluded that she had rapidly progressive interstitial lung disease (RPILD) due to amyopathic dermatomyositis. Despite maximal medical management, she was ultimately transitioned to comfort care measures and expired.

Conclusion: We would like to highlight the rarity of double antibody positive amyopathic dermatomyositis. This unique clinical presentation has only been reported in persons of Japanese descent. Our case is likely to be the first reported to occur in a person of Hispanic descent in the United States.

The rarity of our case could stimulate further study of overlapping MSA to understand its varied presentations and prognoses including possible tendency toward a rapidly progressive ILD phenotype. Earlier detection of these clinical syndromes can lead to better outcomes for patients with RPILD. This case report could also herald an increased recognition and understanding of MSA profile in the Hispanic population in the USA.

Keywords: Dermatomyositis, Myositis-specific autoantibodies, Anti-MDA5, Anti-PL-7, Anti-ARS, Rapid progressive interstitial lung disease

\footnotetext{
* Correspondence: Zli@fresno.ucsf.edu

'Department of Internal Medicine, University of California, San

Francisco-Fresno, Fresno, CA, USA

${ }^{2}$ UCSF Fresno Medical Education Program, Internal Medicine, 155 N Fresno

St, Fresno, CA 93701, USA

Full list of author information is available at the end of the article
}

(c) The Author(s). 2020 Open Access This article is licensed under a Creative Commons Attribution 4.0 International License, which permits use, sharing, adaptation, distribution and reproduction in any medium or format, as long as you give appropriate credit to the original author(s) and the source, provide a link to the Creative Commons licence, and indicate if changes were made. The images or other third party material in this article are included in the article's Creative Commons licence, unless indicated otherwise in a credit line to the material. If material is not included in the article's Creative Commons licence and your intended use is not permitted by statutory regulation or exceeds the permitted use, you will need to obtain permission directly from the copyright holder. To view a copy of this licence, visit http://creativecommons.org/licenses/by/4.0/. The Creative Commons Public Domain Dedication waiver (http://creativecommons.org/publicdomain/zero/1.0/) applies to the data made available in this article, unless otherwise stated in a credit line to the data. 


\section{Background}

Myositis-specific autoantibodies (MSAs) are comprised of anti-aminoacyl-tRNA synthetase (anti-ARS) and non-anti-synthetase groups. These antibodies have differences in their pathophysiology profiles and clinical presentations, and are not usually known to coexist. Each anti-aminoacyl-tRNA synthetase (antiARS) antibodies tend to have its own unique presentation or combinations of myositis, interstitial lung disease (ILD) patterns, and skin manifestations. The MSAs include anti-EJ (glycyl) and anti-PL7(threonyl) antibodies [1] Anti-melanoma differentiation-associated gene 5 (MDA5) antibody is one of the non-antisynthetase MSAs, which uniquely presents as clinically-amyopathic dermatomyositis (CADM), with its well-known potentially fatal course due to rapidly progressive ILD [2]. We only found two reported cases in Japan with double MSAs. The first one has anti-PL-7(threonyl) and anti-MDA5, and the second case with anti-EJ (glycyl) and anti-MDA5 [3, 4]. We report our case of a Hispanic patient instead of Asian descent as described in prior case reports, in addition to being possibly the first reported double-positive MSA-CADM case in the United States.

\section{Case presentation}

A 27-year-old Hispanic female with chronic hirsutism and oligomenorrhea presented to an outside hospital in June 2019 with worsening chronic cough for 1 year. Per family, patient was in good health excepted for rash on her chest and knuckles that responded to topical hydrocortisone. There was no evaluation done in the outpatient setting for her chronic cough. She had presented to an urgent care where she was prescribed azithromycin 2 days prior to hospitalization.

On presentation to the outside hospital, she was febrile, tachycardic, tachypneic, with an oxygen saturation of $85 \%$ on nasal cannula at $15 \mathrm{~L} / \mathrm{min}$. Respiratory exam was significant for rhonchi bilaterally. Initial labs showed normal white blood cell count, normal creatine, and slightly elevated globulin with normal liver function tests. Her streptococcus pneumonia urinary antigen was positive. She was treated with a course of antibiotics. Computed tomography (CT) scan of the chest revealed no pulmonary embolus and demonstrated bilateral diffuse ground glass patchy opacities throughout the lungs (Fig. 1a-b).

She was initially admitted to the medical intensive care unit and intubated for hypoxemic respiratory failure due to acute respiratory distress syndrome (ARDS). Broad spectrum antibiotic therapy was started with intravenous piperacillin /tazobactam and levofloxacin. She was on maximal ventilatory support at the outside hospital and continued to remain hypoxemic with elevated peak and plateau pressures. Neuromuscular blockade was initiated, with only minimal improvement in oxygenation. Prone positioning was not attempted at the outside hospital. She was transferred to our hospital on day 7 of her course for evaluation of veno-venous extra corporeal membrane oxygenation (VV-ECMO).

On arrival to our hospital, her $\mathrm{PaO} 2 / \mathrm{FiO} 2$ ratio was 40 despite maximal ventilator support and neuromuscular blockade. Given she had failed conventional ARDS treatments, VV ECMO was initiated. Bronchoscopy was performed and revealed no signs of diffuse alveolar hemorrhage (DAH), and infectious workup from bronchial lavage was negative.

Further workup at our center revealed mildly elevated aldolase, low-normal creatine kinase, and elevated transaminases. Autoimmune labs revealed positive antinuclear antibody (ANA), positive SS-A antibodies, elevated rheumatoid factor, elevated anti-PL-7 and anti MDA5 antibody levels detected by commercial immunoblot assay kit (Myositis Specific 11 Antibodies Panel, Quest Diagnostic, USA), and which was confirmed with repeated testing (Table 1).

Physical examination revealed diffuse facial hair and hyperpigmented patches at the dorsum of bilateral third metacarpophalangeal joints (Fig. 2). These skin features,

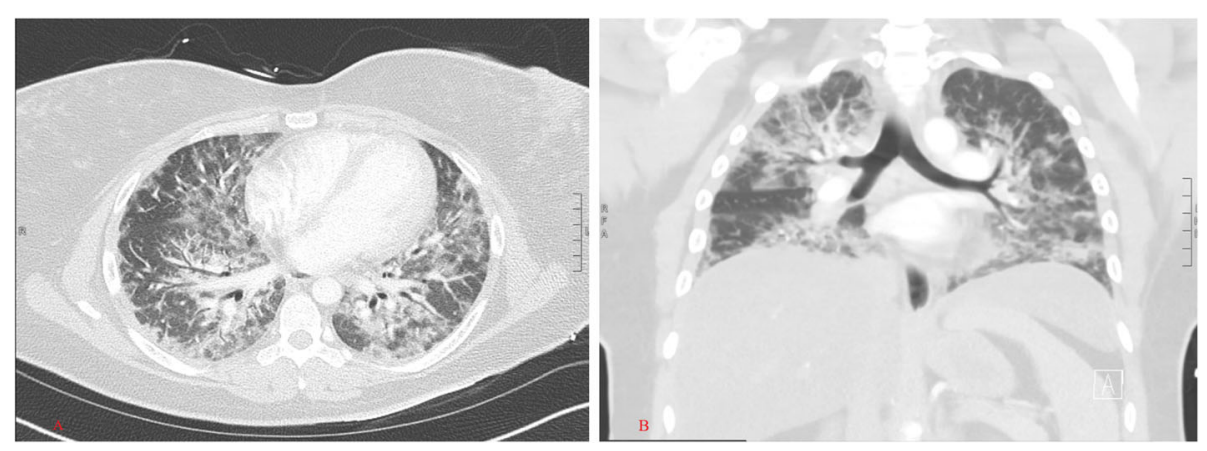

Fig. 1 a-b: CT of the thorax showing diffuse ground glass opacities at the axial view (1a) and at the coronal view (1b) 
Table 1 Laboratory test

Test name
Hematology
Hemogle blood count
Platelet count
Chemistry
Aldolase
Creatine kinase
Alanine aminotransferase (ALT)
Lactic Acid
Infectious
Culture, Blood
Culture, Respiratory aspiration
Culture, Fungal in respiratory aspiration
Culture, Urine
Cocci-Direct PCR
Legionella Urine antigen
Mycoplasma Pnuemoniae
Strep Pneumoniae Urine antigen
Upper respiratory viral panels
Influenza A/B PCR
HIV AB AG screen

\section{Autoimmune}

Anti-neutrophil cytoplasmic antibody (ANCA)

Antinuclear antibody reflex (ANA)

SS-A/Ro lgG antibody

SS-B/La lgG antibody

Anti-topoisomerase (SCL-70) IgG antibody

Centromere auto antibody

Double strand DNA (dsDNA)

Smith $\lg G$

Ribonucleic protein (U1 RNP/snRNP) IgG

Myositis panel (collection date: Hospital Day 8)

Value (reference range)

$9.110^{3} / \mathrm{uL}$ at Day 1 of admission Range from 5.3-9.7 10 $/ \mathrm{uL}$ during hospital stay $\left(4.0-11.010^{3} / \mathrm{uL}\right)$

$12.8 \mathrm{~g} / \mathrm{dL}$ at Day 1 of admission

Range from $6.1-12.8 \mathrm{~g} / \mathrm{dL}$ during hospital stay $(12-16 \mathrm{~g} / \mathrm{dL})$

$26010^{3} / \mathrm{uL}$ at Day 1 of admission

Range from 68.0-260 103/uL during stay (140-440 103/uL)

\section{$12.4(<8.2 \mathrm{U} / \mathrm{L})$}

17 to $26 \mathrm{U} / \mathrm{L}$ during admission (25-140 U/L)

15 to $227 \mathrm{U} / \mathrm{L}$ during admission (7-35 U/L)

$2.1 \mathrm{mmol} / \mathrm{L}$ at day 1 of admission

Range from $0.9-4.1 \mathrm{mmol} / \mathrm{L}$ during admission stay

No growth

No growth

No growth

No growth

Negative

Negative

Negative

Positive

Negative

Negative

Negative

Negative

Positive, titer 1:160

1.2 positive ( $<1.0$ Negative)

$<1.0$ Negative $(<1.0$ Negative)

$<1.0$ Negative $(<1.0$ Negative)

$<1.0$ Negative $(<1.0$ Negative)

$1 \mathrm{IU} / \mathrm{mL}(<5 \mathrm{IU} / \mathrm{mL})$

$<1.0$ negative $(<1.0$ Negative)

$<1.0$ negative $(<1.0$ Negative)

Jo-1 Ab $<11(<11 \mathrm{SI})$

\section{PL-7 Ab 60 (< 11 SI)}

PL-12 Ab $<11(<11 \mathrm{SI})$

EJ $\mathrm{Ab}<11(<11 \mathrm{SI})$

OJ $\mathrm{Ab}<11(<11 \mathrm{SI})$

SRP Ab $<11(<11$ SI

Mi-2 Alpha Ab $<11(<11 \mathrm{SI})$

Mi-2 Beta $\mathrm{Ab}<11(<11 \mathrm{SI})$

MDA-5 Ab 89 (< 11 SI)

TIF-1y Ab $<11(<11 \mathrm{SI})$ 
Table 1 Laboratory test (Continued)

\begin{tabular}{|c|c|}
\hline Test name & Value (reference range) \\
\hline & NXP-2 Ab < $11(<11 \mathrm{SI})$ \\
\hline \multirow[t]{11}{*}{ Myositis panel (collection date: Hospital Day 16) } & Jo-1 Ab < $11(<11 \mathrm{SI})$ \\
\hline & PL-7 Ab61 (< $11 \mathrm{SI})$ \\
\hline & PL-12 Ab < $11(<11 \mathrm{SI})$ \\
\hline & EJ $\mathrm{Ab}<11(<11 \mathrm{SI})$ \\
\hline & OJ $\mathrm{Ab}<11(<11 \mathrm{SI})$ \\
\hline & SRP Ab $<11(<11 \mathrm{SI}$ \\
\hline & Mi-2 Alpha Ab $<11(<11 \mathrm{SI})$ \\
\hline & Mi-2 Beta Ab < $11(<11 \mathrm{SI})$ \\
\hline & MDA-5 Ab $78(<11 \mathrm{SI})$ \\
\hline & TIF-1y Ab < $11(<11 \mathrm{SI})$ \\
\hline & NXP-2 Ab < $11(<11 \mathrm{SI})$ \\
\hline
\end{tabular}

Jo-1 (antihistidyl-tRNA synthetase), PL-7 (threonyl), PL-12 (alanyl), EJ (glycyl), OJ (isoleucyl), Mi-2 (Mi-2/nucleosome remodelling and deacetylase (NuRD), SRP (signal recognition particle), MDA5 (melanoma-differentiation associated gene 5), TIF-1 y (intermediary factor 1-gamma), NXP-2(nuclear matrix protein),

along with the lack of muscle weakness and unremarkable muscle enzymes, CT chest findings of bilateral ground glass opacities, double positive MSAs (anti-PL-7 and MDA5), and negative infectious work up, all led to a diagnosis of acute hypoxemic respiratory failure secondary to rapidly progressive interstitial lung disease (RPIL D) due to CADM.

Patient remained on maximal support from the ECMO circuit and the ventilator. Pulse doses of methylprednisolone $1 \mathrm{~g}$ daily was initiated on day 10 , intravenous immune globulin (IVIG) was given on day 17, and rituximab was given on day 19. She was then transitioned to methylprednisolone $60 \mathrm{mg}$ daily on day 20. Repeat CT chest on day 21 showed worsening of consolidation and persistent patchy GGO bilaterally.

She was eventually transferred to a lung transplant center on day 24 given no significant improvement despite on VV-ECMO and maximal ventilator support for 17 days. After a detailed evaluation by multi-

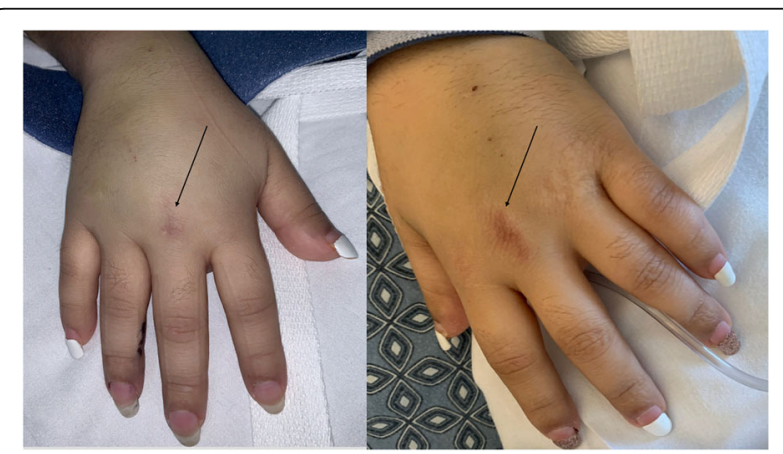

Fig. 2 Bilateral forme fruste of Gottron's patches at the third metacarpophalangeal joints (black arrows) disciplinary team at the lung transplant center, she was deemed not to be a lung transplant candidate. Her family had decided to transition to comfort care on day 33 and patient expired.

\section{Discussion and conclusions}

The clinical features associated with certain MSA can usually be distinct from one another. Anti PL-7 antibodies are classified under the anti-ARS group. These antibodies are associated with a median age of clinical onset of 60 years old with $90 \%$ having non-specific interstitial pneumonia (NSIP) on HRCT and elevated serum creatinine kinase [5]. Anti-MDA5 antibody cases were mostly reported in Japan and rural China; $90 \%$ of them have dermatomyositis related skin findings and pulmonary findings of acute ILD with consolidation and ground glass attenuation [5]. Chest CT of MDA5-ILD is reportedly characterized by lower lung consolidation or a random GGO pattern with absence of intralobular reticular opacities and traction bronchiectasis [6]. Anti-MDA5 associated ILD carry a poorer prognosis as compared to anti-ARS associated ILD [7].

In the case reported by Naniwa et al, they described a patient who tested positive for PL-7 and MDA5 antibodies and had chest $\mathrm{CT}$ features of the corresponding antibodies at the time of onset for RPILD, which had improved pulmonary function after high dose of IVIG [3]. In another case written by Takeuchi et al, their patient's double MSAs dermatomyositis-ILD was associated with anti-EJ and anti-MDA5 antibodies. During the initial course, chest CT had peripheral ground glass attenuation, marked reticulation, traction bronchiectasis and volume loss in the lower lung field bilaterally that were 
consistent with anti-ARS ILD associated disease, even though patient had anti-EJ and anti-MDA5 positive. The patient later gained anti-MDA5 ILD associated features during an acute exacerbation phase, at which time only anti-MDA5 antibodies were positive [4].

In contrast to these previous two cases of anti-ARS antibodies with co-existent anti-MDA5, our patient's chest CT had extensive ground glass opacities bilaterally without bronchiectasis, which is more indicative of the pulmonary features for anti MDA5 ILD. Interestingly, she was found to have positive testing for both anti-PL7 and anti-MDA5 on repeated MSAs panel testing. Further comparison among these three cases is listed at Table 2.

Different from the previous two cases which used immunoprecipitation methods, our case was tested with immunoblot assay MSA panel testing via Quest Diagnostics. This was repeated later to ensure no false positivity, and results remained positive at similar levels for each antibody. According to the study done by Cavazzana et.al, there was lower agreement rate for anti-Jo antibodies, and higher agreement rate for anti-MDA-5 antibodies when analyzing the performance of immunoblot assay and immunoprecipitation, but there has been no comparison between these 2 methods for Anti-PL-7 antibodies [8].

Dermatomyositis with unique MSA profiles are increasingly recognized for its varied presentations but with unclear overlapping prognoses, and even more elusive associations with malignancies. Certain features, such as RPILD may be a common denominator for some of the MSA profiles. Of note, the hyperpigmented patches over bilateral third MCP joints are likely a forme fruste of Gottron's patches. Cognizance of these rashes in its potentially slightest expression may give a clue to solidify a dermatomyositis diagnosis.

Survival rates vary, with anti-MDA5 having the poorest reported survival [7]. Since most of the anti-MDA5 associated dermatomyositis cases were mostly reported in Asian countries, it is still unclear if the prognosis will be different in other ethnic groups, or if it will be different for similar ethnic groups living outside the Asian geographic regions.

The pathogenesis of double positive MSAs in amyopathic dermatomyositis is largely unclear given the rarity of reported data. There is neither MSA-specific therapy guideline for CADM/ILD, nor for doubleantibody positive cases. Glucocorticoid monotherapy or in combination with immunosuppressants, IVIG, cyclophosphamide, rituximab, plasmapheresis have been observed in current practices with varied outcomes.

Further study into MSA profiles in the Hispanic population will be helpful to understand the prevalence, prognoses, and outcomes of these potentially life-threatening myositis syndromes. Such studies may lead to further insight into the pathogenesis of myositis and whether differences in profile patterns translate into varying clinically outcomes.

Table 2 Comparison on coexistent anti-aminoacyl-tRNA synthetase (anti-ARS)-interstitial lung disease (ILD) dermatomyositis with anti-melanoma differentiation-associated gene 5 (MDA5)-ILD dermatomyositis

\begin{tabular}{|c|c|c|c|}
\hline & Naniwa et al. [3] & Takecuchi et al. [4] & Current case \\
\hline Patient ethnicity & Japanese & Japanese & Hispanic \\
\hline Gender & Male & Female & Female \\
\hline Age & 70-year-old & 53-year-old & 27-year-old \\
\hline $\begin{array}{l}\text { Anti-ARS } \\
\text { antibodies }\end{array}$ & $\begin{array}{l}\text { Yes, anti-threonyl-transfer RNA syn- } \\
\text { thetase (anti-PL-7) }\end{array}$ & Yes, Anti-glycyl-tRNA synthetase (anti-EJ) & $\begin{array}{l}\text { Yes, anti-threonyl-transfer RNA } \\
\text { synthetase (anti-PL-7) }\end{array}$ \\
\hline $\begin{array}{l}\text { Anti-MDA-5 } \\
\text { antibodies }\end{array}$ & Yes & Yes & Yes \\
\hline $\begin{array}{l}\text { Diagnostic testing } \\
\text { tool }\end{array}$ & Immunoprecipitation assay & Immunoprecipitation assay & Commercial Immunoblot assay \\
\hline Skin manifestation & $\begin{array}{l}\text { Facial rash, a V-sign rash, a periun- } \\
\text { gual erythema, and nail fold } \\
\text { bleeding }\end{array}$ & $\begin{array}{l}\text { heliotrope rash, facial erythema, Gottron papules with } \\
\text { some shallow ulcers, mechanic's hands and periungual } \\
\text { erythema }\end{array}$ & $\begin{array}{l}\text { forme fruste of Gottron's } \\
\text { patches }\end{array}$ \\
\hline $\begin{array}{l}\text { Pulmonary } \\
\text { Manifestation }\end{array}$ & $\begin{array}{l}\text { Fine crackles were heard bilaterally } \\
\text { in the lower lung field }\end{array}$ & $\begin{array}{l}\text { Lung auscultation identified considerable fine crackles } \\
\text { bilaterally }\end{array}$ & $\begin{array}{l}\text { Diffuse crackles at lung } \\
\text { auscultation bilaterally }\end{array}$ \\
\hline $\begin{array}{l}\text { Chest computed } \\
\text { tomography } \\
\text { findings }\end{array}$ & Not done & $\begin{array}{l}\text { Initial presentation with anti-EJ only: lower peripheral } \\
\text { reticulation and ground-glass attenuation (GGA) } \\
\mathbf{1 5} \text { years after onset during exacerbation with anti- } \\
\text { MDA5 only: } \\
\text { rapidly progressive course with newly developed random } \\
\text { GGA }\end{array}$ & $\begin{array}{l}\text { Extensive ground glass } \\
\text { opacities bilaterally without } \\
\text { bronchiectasis }\end{array}$ \\
\hline
\end{tabular}




\section{Abbreviations}

ARDS: Acute respiratory distress syndrome; CT: Computed tomography; GGO: Diffuse ground glass opacities; HRCT: High resolution computed tomography; IVIG: Intravenous immunoglobulin; MSA: Myositis-specific autoantibody; Anti-ARS: Anti-aminoacyl-tRNA synthetase; RPILD: Rapid progressive interstitial lung disease; W-ECMO: Veno-venous Extra Corporeal Membrane Oxygenation

\section{Acknowledgements}

We thank Dr. Mohammed Fayed for his invaluable assistance in identifying $\mathrm{CT}$ chest images.

\section{Authors' contributions}

Dr. Li was responsible for prepared and drafted the manuscript. Dr. Gill prepared the $C T$ chest images and performed literature review of the manuscript. Dr. Mo performed review and revision of the manuscript. Dr. Reyes provided critically revision of the manuscript. The author(s) read and approved the final manuscript.

\section{Funding}

Not applicable.

\section{Availability of data and materials}

Not applicable.

\section{Ethics approval and consent to participate}

Not applicable.

\section{Consent for publication}

A written consent to publish this information was obtained from study participant's family.

\section{Competing interests}

The authors declare that they have no competing interests.

\section{Author details}

'Department of Internal Medicine, University of California, San

Francisco-Fresno, Fresno, CA, USA. ${ }^{2}$ UCSF Fresno Medical Education Program, Internal Medicine, $155 \mathrm{~N}$ Fresno St, Fresno, CA 93701, USA. ${ }^{3}$ Division of Rheumatology, University of California-San Francisco, Fresno, CA, USA.

Received: 1 April 2020 Accepted: 5 August 2020

Published online: 15 August 2020

\section{References}

1. Hamaguchi Y, Fujimoto M, Matsushita T, Kaji K, Komura K, Hasegawa M, et al. Common and distinct clinical features in adult patients with antiaminoacyl-tRNA synthetase antibodies: heterogeneity within the syndrome. PLoS One. 2013;8(4):e60442. https://doi.org/10.1371/journal.pone.0060442 [cited 2019 July 10].

2. Hozumi H, Fujisawa T, Nakashima R, Johkoh T, Sumikawa H, Murakami A et al. Comprehensive assessment of myositis-specific autoantibodies in polymyositis/dermatomyositis-associated interstitial lung disease. Respir Med. 2016;121:91-9. https://doi.org/10.1016/j.rmed.2016.10.019 [cited 2019 July 10] available from https://www.resmedjournal.com/article/S0954-6111 (16)30282-7/fulltext.

3. Naniwa T, Tamechika S, Okazaki Y, Maeda S, Kuwana M. Coexistence of antimelanoma differentiation-associated gene 5 and anti-aminoacyl-transfer RNA synthetase antibodies in a patient with dermatomyositis and rapidly progressive and relapsing interstitial lung disease. Mod Rheumatol Case Rep. 2017;1 (1):3-8. https://doi.org/10.1080/24725625.2016.1253650.

4. Takeuchi Y, Hashimoto M, Nakashima R, Tanaka M, Kuramoto N, Murakami K, Yoshifuji H, Ohmura K, Mimori T. Anti-EJ, anti-MDA5 double-positive chronic clinically amyopathic dermatomyositis: a case report. Rheumatol Adv Pract. 2018;2(2):rky022. https://doi.org/10.1093/rap/rky022.

5. Antibodies \& complement in myopathies and NMJ disorders. Neuromuscular Disease Center [Internet]. Washington University, St. Louis. [Updated 2019 July 10, cited 2019 July 11]. Available from https:// neuromuscular.wustl.edu/lab/mantibody.html.
6. Tanizawa K, Handa T, Nakashima R, et al. HRCT features of interstitial lung disease in dermatomyositis with anti-CADM-140 antibody. Respir Med. 2011; 105:1380-7.

7. Witt LJ, Curran JJ, Strek ME. The diagnosis and treatment of antisynthetase syndrome. Clin Pulm Med. 2016;23(5):218-26. https://doi.org/10.1097/CPM. 0000000000000171

8. Cavazzana I, Fredi M, Franceschini F. Semiquantitative analysis of line blot assay for myositis-specific and myositis-associated antibodies: a better performance? Ann Rheum Dis. 2019. https://doi.org/10.1136/annrheumdis2019-215884.

\section{Publisher's Note}

Springer Nature remains neutral with regard to jurisdictional claims in published maps and institutional affiliations.

\section{Ready to submit your research? Choose BMC and benefit from:}

- fast, convenient online submission

- thorough peer review by experienced researchers in your field

- rapid publication on acceptance

- support for research data, including large and complex data types

- gold Open Access which fosters wider collaboration and increased citations

- maximum visibility for your research: over $100 \mathrm{M}$ website views per year

At BMC, research is always in progress.

Learn more biomedcentral.com/submissions 